\title{
Comparison of cockroach fungal contamination in the clinical and non-clinical environments from Iran
}

\author{
B. Davari, ${ }^{1}$ A.E. Hassanvand, ${ }^{1}$ H. Nasirian, ${ }^{2}$ S. A. Ghiasian, ${ }^{3}$ A. Salehzadeh, ${ }^{1}$ M. Nazari ${ }^{1}$ \\ ${ }^{1}$ Department of Medical Entomology, School of Medicine, Hamadan University of Medical Sciences, Hamadan; \\ ${ }^{2}$ Department of Medical Entomology and Vector Control, School of Public Health, Tehran University of Medical \\ Sciences, Tehran; ${ }^{3}$ Department of Parasitology and Mycology, School of Medicine, Hamadan University of Medical \\ Sciences, Hamadan, Iran
}

\begin{abstract}
Cockroaches have been associated with human environments threatening human health. A cross-sectional study about cockroach fungal contamination in the hospital, restaurant and household environments from Khorramabad, Lorestan province of Iran between August 2015 and March 2016 was done. Sampling was uniformly carried out monthly from the randomly selected sites. Fungi were isolated from the external surfaces of cockroaches using standard method. Periplaneta americana (66.7\%) was found the most infested cockroach, less percentage were observed
\end{abstract}

Correspondence: Hassan Nasirian, School of Public Health, Tehran University of Medical Sciences, Tehran, Iran.

Tel.: +98.21.42933182.

E-mail: hanasirian@yahoo.com

Key words: Blattella germanica; Blatta orientalis; clinical and nonclinical environments; cockroach fungal contamination; Periplaneta americana.

Acknowledgements: this study is the second author's M.Sc. thesis in Medical Entomology and Vector Control from Department of Medical Entomology, School of Medicine, financially supported by Research Deputy of Hamadan University of Medical Sciences (Grant No: 9404302417).

Contributions: the authors contributed equally.

Conflict of interest: the authors declare no potential conflict of interest.

Received for publication: 19 April 2017.

Revision received: 28 May 2017.

Accepted for publication: 28 May 2017.

CCopyright B. Davari et al., 2017

Licensee PAGEPress, Italy

Journal of Entomological and Acarological Research 2017; 49:6758

doi:10.4081/jear:2017.6758

This article is distributed under the terms of the Creative Commons Attribution Noncommercial License (by-nc 4.0) which permits any noncommercial use, distribution, and reproduction in any medium, provided the original author(s) and source are credited. in Blattella germanica (18.6\%) and Blatta orientalis (14.7\%). Hospitals (66.7\%) were found the most infested places in comparison with households (18.6\%) and restaurants $(14.7 \%)$. Households $(64.3 \%)$ were found the most cockroach fungal contaminated places than hospitals $(49.0 \%)$ and restaurants $(59.1 \%)$. The highest and the lowest infestation of cockroaches were observed in January (30.0\%) and March (7.0\%) respectively, while the highest and the lowest cockroach fungal contamination were observed in November (73.3\%) and March (14.3\%). B. germanica $(60.7 \%)$ was the most fungal contaminated cockroach. Candida, Geotrichum and Penicillium were the most frequent cockroach fungal contaminating genera. Statistical analysis revealed significant differences between cockroach infestation places $(\mathrm{P}=0.022)$, locality $(\mathrm{P}=0.03)$, and monthly $(\mathrm{P}=0.0001)$ cockroach fungal contamination, respectively. As a conclusion, the highest cockroach fungal contamination was observed in $B$. germanica, followed by $P$. americana and B. orientalis. Some human fungal opportunistic pathogens were also found among the fungal contaminated cockroaches. Recent epidemiological survey showed that the mortality rates of the infective diseases were increased, indicating cockroaches involved in their transferring.

\section{Introduction}

Cockroaches have been associated with human living environment due to very high compatibility with human habitats (Nasirian, 2016). As infestation of cockroaches are increasing, may be not seen a place that is safe from the presence of cockroaches (Nasirian, 2007; 2008; 2017b; Nasirian et al., 2006e; Limoee et al., 2012; Nazari et al., 2016). Because of presenting in the dirty places, vomiting the eaten foods, defecating feces in the environment and producing bad smell and allergens, cockroaches are harmful to human health (Doroodgar et al., 2005; Stypułkowska-Misiurewicz et al., 2005). The ability of cockroaches to run and move quickly from seams and narrow paths also increases their ability to escape from control methods and their role in the transmission of pathogens and reveals their medical importance more than ever.

Like houseflies the role of cockroaches is clear in the spread of nosocomial infections (Davari et al., 2010; Khoobdel \& Davari, 2011; Davari et al., 2012; Nasirian, 2010; 2017a). Many studies have been conducted about natural cockroach contamination to 
pathogenic fungi. As well as advances in the diagnosis and treatment of diseases and new discovery of diagnostic or therapeutic methods have increased the patients' age, ascending infections due to saprophytic fungi agents are observed.

Recent epidemiological survey showed that the mortality rates of the patients admitted to Shohada Hospital of Khorramabad are increased and the mortality rates of infective diseases were $4.2 \%$ (Mahmoudi et al., 2014).

The city of Khorramabad, the capital of Lorestan province, has a sweet nature with four weather seasons and is a benefit thanks the rich natural and tourist attractions. A cross-sectional study about contamination of cockroaches to fungi in the hospital, restaurant and household environments of Khorramabad, Lorestan province was carried out between August 2015 and March 2016.

\section{Materials and methods}

\section{Site of study}

The sites of study were randomly selected from the hospital, restaurant and household environments in Khorramabad. The selected hospitals were Shohaday-e-Ashayer Medical Education Center and Shahid Madani Specialized hospital. The Shohaday-eAshayer Medical Education Center is the largest and the best equipped Medical Education Center of Lorestan University of Medical Sciences with 350 beds. It has more than 20 Specialized and Super-specialized units. Shahid Madani Specialized hospital has 60 beds. We also selected 6 households and 6 restaurants from Khorramabad city including one from the each north, south, east, west and 2 from the center.

\section{Sampling of cockroaches and identification}

Sampling was uniformly carried out monthly for three hours from each sites of the study using Nasirian et al. methods (Nasirian et al., 2006c; 2009) between August 2015 and March 2016, 150 samples were collected to allow a good statistical estimate. Cockroaches were transferred to a sterilized wide mouth glass container after collecting by hand catch. Each container was allocated only to one cockroach to avoid mixing contamination of cockroaches to each other. Then the samples were transported to the laboratory after closing their mouth by a piece of cloth and elastic ring around it. The cockroaches were identified with cockroach taxonomic keys after their anesthetizing by placing them in the freezer for 5 minutes in the laboratory.

\section{Fungal isolation and identification}

In order to avoid possible microorganisms contamination from the external surfaces of cockroaches, each cockroach was placed into a sterile glass containing $5 \mathrm{ml}$ of normal saline solution. Then they were shaken strongly and washed. To isolate fungi from the external surfaces of cockroaches, $2 \mathrm{~mL}$ of the obtained suspension was centrifuged for $10 \mathrm{~min}$ at $2000 \mathrm{rpm}$. Then the residues were cultured on medium plates of dextrose agar with the addition of Chloramphenicol. The plates were incubated at $25^{\circ} \mathrm{C}$ for one week. When fungal identification was impossible, the colony was cultured using culture slides (Ash \& Greenberg, 1980; Zaeim et al., 2008). Finally, the fungi were recognized based on the fungal identification keys and the data were filed for statistical analysis among cockroach infestation places, locality contamination, monthly fungal contamination and species fungal contamination.

\section{Statistical analysis}

Chi-square test was used to compare the frequency of fungal pathogens using SPSS version 16 software. In the all statistical tests $\mathrm{P}<0.05$ was considered as statistically significant level.

\section{Results}

Table 1 and Figure 1 show cockroach infestation between August 2015 and March 2016 in the sites of study. Three cockroach species including Blattella germanica (German cockroach), Blatta orientalis (Oriental cockroach) and Periplaneta americana (American cockroach) were identified. Periplaneta americana was found the most infested cockroach species (Figure 1A). As observed (Figure 1C) the cockroach infestation ranged from $4.7 \%$ in March to $20.0 \%$ in January. Hospitals $(66.7 \%)$ were found the most cockroach infested places than households (18.6\%) and restaurants (14.7\%). Statistical analysis revealed significant differences between cockroach infestation places including households, hospitals and restaurants ( $\mathrm{P}=0.022$ ) (Table 2).

Table 3 shows the lists of isolated fungal pathogens from collected cockroaches and locality of selected sites of the study. Among cockroaches collected from the selected hospitals $(n=100)$, 51 cockroaches were without any fungal contamination and 49 samples were contaminated with fungal pathogens. The most cockroach fungal contamination was related to Penicillium and yeast. Among cockroaches collected from the selected households $(\mathrm{n}=28), 10$ cockroaches were without any fungal contamination

Table 1. Cockroach infestation between August 2015 and March 2016 in the sites of study.

\begin{tabular}{|c|c|c|c|c|c|c|c|c|c|c|c|c|}
\hline \multirow{2}{*}{$\begin{array}{l}\text { Species } \\
\text { B. germanica }\end{array}$} & Sites & Aug & Sept & Oct & Nov & Dec & Jan & Feb & Mar & \multicolumn{2}{|c|}{ Sites, total } & Cockroach, \% \\
\hline & $\begin{array}{c}\text { Hospitals } \\
\text { Households } \\
\text { Restaurants }\end{array}$ & $\begin{array}{l}2 \\
1 \\
2\end{array}$ & $\begin{array}{l}2 \\
2 \\
1\end{array}$ & $\begin{array}{l}5 \\
3 \\
2\end{array}$ & $\begin{array}{l}4 \\
0 \\
0\end{array}$ & $\begin{array}{l}4 \\
0 \\
0\end{array}$ & $\begin{array}{l}0 \\
0 \\
0\end{array}$ & $\begin{array}{l}0 \\
0 \\
0\end{array}$ & $\begin{array}{l}0 \\
0 \\
0\end{array}$ & $\begin{array}{l}17 \\
6 \\
5\end{array}$ & $\begin{array}{l}11.3 \\
4.0 \\
3.3\end{array}$ & 18.6 \\
\hline B. orientalis & $\begin{array}{c}\text { Hospitals } \\
\text { Households } \\
\text { Restaurants }\end{array}$ & $\begin{array}{l}0 \\
4 \\
2\end{array}$ & $\begin{array}{l}0 \\
5 \\
3\end{array}$ & $\begin{array}{l}3 \\
0 \\
0\end{array}$ & $\begin{array}{l}0 \\
0 \\
5\end{array}$ & $\begin{array}{l}0 \\
0 \\
0\end{array}$ & $\begin{array}{l}0 \\
0 \\
0\end{array}$ & $\begin{array}{l}0 \\
0 \\
0\end{array}$ & $\begin{array}{l}0 \\
0 \\
0\end{array}$ & $\begin{array}{c}3 \\
9 \\
10\end{array}$ & $\begin{array}{l}2.0 \\
6.0 \\
6.7\end{array}$ & 14.7 \\
\hline P. americana & $\begin{array}{c}\text { Hospitals } \\
\text { Households } \\
\text { Restaurants }\end{array}$ & $\begin{array}{l}5 \\
2 \\
2\end{array}$ & $\begin{array}{l}4 \\
2 \\
2\end{array}$ & $\begin{array}{l}6 \\
4 \\
1\end{array}$ & $\begin{array}{l}6 \\
0 \\
0\end{array}$ & $\begin{array}{l}9 \\
5 \\
2\end{array}$ & $\begin{array}{c}30 \\
0 \\
0\end{array}$ & $\begin{array}{c}13 \\
0 \\
0\end{array}$ & $\begin{array}{l}7 \\
0 \\
0\end{array}$ & $\begin{array}{c}80 \\
13 \\
7\end{array}$ & $\begin{array}{c}53.3 \\
8.7 \\
4.7\end{array}$ & 66.7 \\
\hline Total & $\begin{array}{c}\text { No } \\
\%\end{array}$ & $\begin{array}{c}20 \\
13.3\end{array}$ & $\begin{array}{c}21 \\
14.0\end{array}$ & $\begin{array}{c}24 \\
16.0\end{array}$ & $\begin{array}{c}15 \\
10.0\end{array}$ & $\begin{array}{c}20 \\
13.3\end{array}$ & $\begin{array}{c}30 \\
20.0\end{array}$ & $\begin{array}{l}13 \\
8.7\end{array}$ & $\begin{array}{c}7 \\
4.7\end{array}$ & $\begin{array}{l}150 \\
100\end{array}$ & $\begin{array}{c}100 \\
-\end{array}$ & \\
\hline
\end{tabular}


and 18 samples were contaminated with fungal pathogens. The most cockroach fungal contamination was related to Geotrichum and Candida. In addition, among cockroaches collected from the selected restaurants $(n=22), 9$ cockroaches were without any fungal contamination and 13 samples were contaminated with fungal pathogens. The most cockroach fungal contamination was related to Geotrichum (Table 3 and Figure 2A,C).

Table 4 shows the lists of isolated fungal pathogens during the study. The highest and the lowest cockroach fungal contamination were observed in the January $(n=16)$ and March $(n=1)$, respectively (Figure 2B). Furthermore, the most abundant fungi were Penicillium, yeast and Geotrichum in order (Figure 2). The most cockroach fungal contamination was related to Penicillium and yeast (Figure 2C). The Oriental cockroaches were mostly contaminated by Geotrichum. The American cockroaches were mostly contaminated by Penicillium and yeast while the German cockroaches were mostly contaminated by Candida (Figure 2C). Statistical analysis didn't reveal significant differences between fungal contamination of the cockroach species ( $\mathrm{P}=0.076)$ (Table 2).

Figure 3 shows cockroach fungal contamination between August 2015 and March 2016 in the sites of study. B. germanica cockroaches $(60.7 \%)$ was mostly contaminated to fungi than the other species (Figure 3A), even though statistical analysis didn't reveal significant differences between fungal contamination of the cockroach species $(\mathrm{P}=0.076)$ (Table 2$)$. According to cockroach collection locality, households $(64.3 \%)$ were found the most cockroach fungal contaminated places than hospitals $(49.0 \%)$ and restaurants (59.1\%) (Figure 3B). Statistical analysis revealed significant differences between the fungi isolated from cockroaches collected from hospital and household environments $(\mathrm{P}=0.03)$ (Table 2). The cockroach fungal contamination during the study ranged from $14.3 \%$ for March to $73.3 \%$ for November (Figure 3C,D). Statistical analysis revealed significant differences between monthly cockroach fungal contamination ( $\mathrm{P}=0.0001)$ (Table 2).

\section{Discussion}

In the present study three cockroach species including Periplaneta americana (66.7\%), Blattella germanica (18.6\%) and Blatta orientalis $(14.7 \%)$ were found. Similar results were found by Zarchi \& Vatani (2009) in Tehran (Zarchi \& Vatani, 2009). P. americana and $B$. germanica species were also found as dominant cockroach species in Zanjan, Sari and Kashan from Iran. The highest and the lowest cockroach infestation during the study were observed in January (20.0\%) and March (4.7\%), respectively (Figure 1C). Statistical analysis also revealed significant differences between cockroach infestation places including households, hospitals and restaurants $(\mathrm{P}=0.022)$ (Table 2$)$. Cockroach populations were increased at the beginning of winter season in coincidence with turning on of heating appliances, while population of cockroaches were decreased at the end of the cold season when heating appliances were turned off.

Our study confirms that hospitals $(66.7 \%)$ were found the most cockroach infested places respect to households $(18.6 \%)$ and restaurants (14.7\%). Different groups of fungi were isolated from the cockroaches in the hospital, restaurant and household environments. The diversity and dominancy of fungal contamination in cockroach species was higher in $P$. americana than in $B$. germanica and $B$. orientalis. Some human fungal opportunistic pathogens were also found among the cockroach contaminated fungi threatening human health (Tables 3 and 4). Statistical
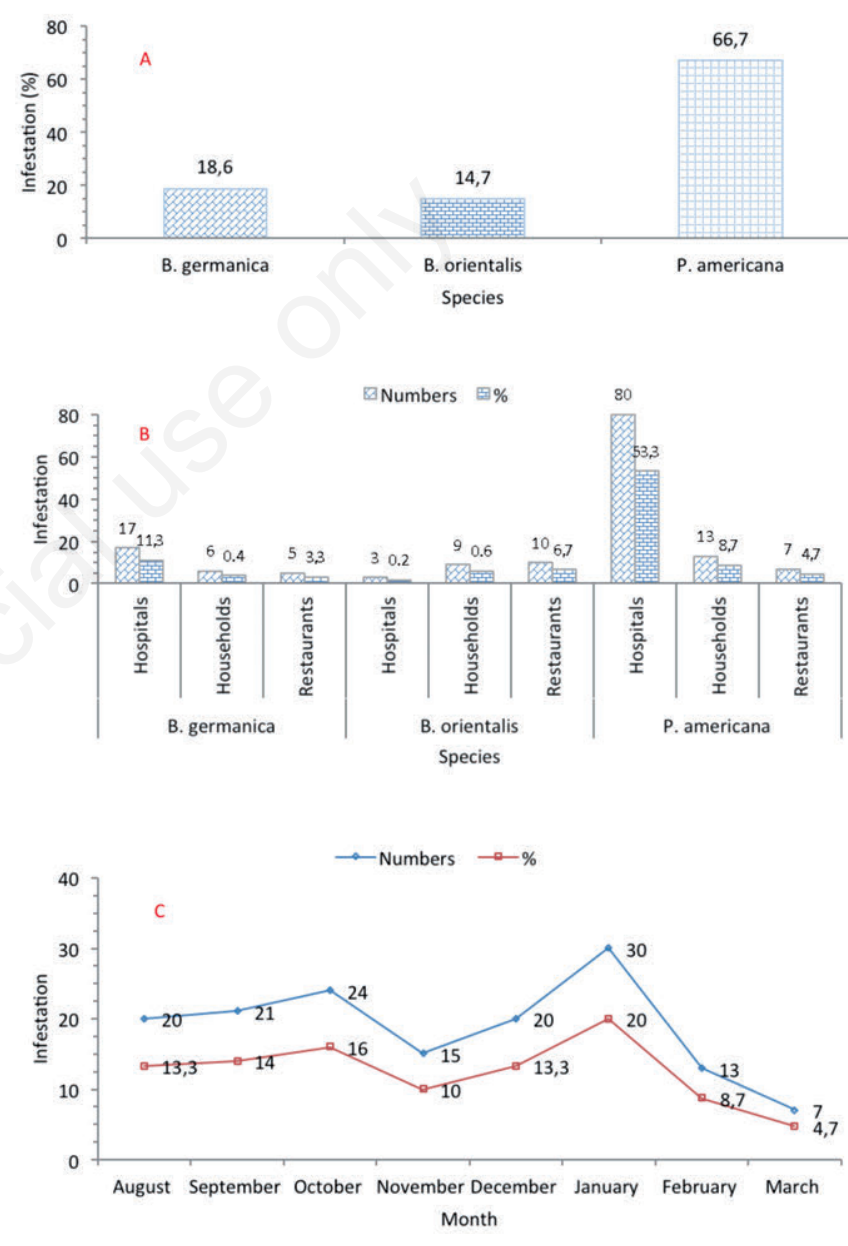

Figure 1. Cockroach infestation between August 2015 and March 2016 in the sites of study. A) Cockroach species infestation. B) Cockroach infestation in the sites of study. C) Trend of cockroach infestation during the study.

Table 2. Pearson Chi-Square statistical analyses, August 2015-March 2016.

\begin{tabular}{lccc} 
Pearson Chi-Square tests & Value & Sig. (2-sided) \\
Between cockroach infestation places & 67.281 & 46 \\
Between cockroach locality contamination & 23.250 & 8.0220 & 0.0300 \\
\hline Between cockroach monthly fungal contamination & 228.847 & 161 \\
Between cockroach species fungal contamination & 60.373 & 46 \\
\hline
\end{tabular}


analysis didn't reveal significant differences between fungal contamination of the cockroach species $(\mathrm{P}=0.076)$ (Table 2). It means that the importance of cockroach species to be contaminated with fungal agents is usually similar. The German cockroaches were mostly found in the clinical environments and the American cockroaches were mostly found in the non-clinical environments (Pai et al., 2004).

In this study different groups of fungi were isolated from the cockroaches. Some human opportunistic pathogens were found among them threatening human health. The increasingly resistance of cockroaches to various insecticide groups is an additional problem (Nasirian et al., 2006a; 2006b; 2006d; 2011; Limoee et al., 2010; Paksa et al., 2011, 2012; Ladonni et al., 2013). In accordance with the study conducted by Fotedar \& Banerjee (1992), the present study revealed significant differences between the fungi isolated from cockroaches collected from hospital and household environments $(\mathrm{P}=0.03)$, and between monthly cockroach fungal contamination ( $\mathrm{P}=0.0001)$ (Table 2). Naderinasab and Moravvej (2012) also found significant differences between the fungi isolated from cockroaches collected from different wards of hospitals and residential areas. Similar to the present study, Chitsazi et al.
(2013) found Penicillium as the most cockroach fungal contaminant in the hospital environments (Fotedar \& Banerjee, 1992; Naderinasab \& Moravvej, 2012; Chitsazi et al., 2013).

The highest and the lowest cockroach fungal contamination during the study were observed in November (73.3\%) and March $(14.3 \%)$, respectively (Figure 3B,C). Statistical analysis also revealed significant differences between monthly cockroach fungal contamination $(\mathrm{P}=0.0001)$ (Table 1$)$, understanding the reason of this observation needs further investigation.

\section{Conclusions}

Cockroaches are the major transmitter of fungal pathogens and allergen-causing agents, so their presence in the public places such as hospital, restaurant and household environments is dangerous and threaten human health. Therefore, in this study, we examine to consider and compare the dominant cockroach fungal contaminants in the hospital, restaurant and household environments of Khorramabad.

Table 3. List of fungi isolated from locality and cockroach species fungal contamination, August 2015-March 2016.

\begin{tabular}{|c|c|c|}
\hline Hospitals & $\begin{array}{l}\text { Locality cockroach fungal contamination } \\
\text { Households }\end{array}$ & Restaurants \\
\hline $\begin{array}{l}\text { Acremonium; Alternaria; Alternaria and } \\
\text { Cladosporium; Candida; Candida and } \\
\text { Geotrichum; Candida and Rhodotorula; Candida, } \\
\text { Mucor and Aspergillus; Cladosporium; } \\
\text { Geotrichum; Mucor, Penicillium; Penicillium and } \\
\text { yeast: Penicillium, Cladosporium and Aspergillus; } \\
\text { Rhizopus and Geotrichum; Yeast. }\end{array}$ & $\begin{array}{c}\text { Acremonium; Aspergillus niger and yeast; } \\
\text { Candida; Candida and Geotrichum; Candida and } \\
\text { Rhodotorula; Cladosporium and Candida; } \\
\text { Cryptosporidium and yeast; Geotrichum; } \\
\text { Penicillium; Penicillium and Acremonium; } \\
\text { Penicillium, Cladosporium and Aspergillus; } \\
\text { Rhodotorula; Yeast. }\end{array}$ & $\begin{array}{c}\text { Acremonium; Alternaria and Cladosporium; } \\
\text { Aspergillus terreus; Candida; Candida and } \\
\text { Geotrichum; Cladosporium; Geotrichum; } \\
\text { Penicillium and Candida. }\end{array}$ \\
\hline P. americana & $\begin{array}{l}\text { Cockroach species fungal contamination } \\
\qquad \text { B. germanica }\end{array}$ & B. orientalis \\
\hline $\begin{array}{c}\text { Acremonium; Alternaria Alternaria and } \\
\text { Cladosporium; Candida; Candida and } \\
\text { Geotrichum; Candida and Rhodotorula; Candida, } \\
\text { Mucor and Aspergillus; Cladosporium; } \\
\text { Cryptosporidium and yeast; Geotrichum; Mucor; } \\
\text { Penicillium, Penicillium and yeast; Penicillium; } \\
\text { Cladosporium and Aspergillus; Rhizopus and } \\
\text { Geotrichum; Yeast. }\end{array}$ & $\begin{array}{l}\text { Alternaria and Cladosporium; Aspergillus niger } \\
\text { and yeast; } \text { Aspergillus terreus; Candida; Candida } \\
\text { and Geotrichum; Candida, Mucor and Aspergillus; } \\
\text { Cladosporium; Cladosporium and Candida; } \\
\text { Geotrichum; Penicillium; Penicillium and } \\
\text { Acremonium; Penicillium and Candida; } \\
\text { Penicillium, Cladosporium and Aspergillus }\end{array}$ & $\begin{array}{l}\text { Acremonium; Alternaria and Cladosporium; } \\
\text { Candida; Candida and Rhodotorula Geotrichum; } \\
\text { Penicillium and Candida; Rhodotorula;Yeast }\end{array}$ \\
\hline
\end{tabular}

Table 4. List of monthly fungi isolated from cockroaches, August 2015 and March 2016.

\begin{tabular}{|c|c|c|c|c|c|c|c|}
\hline Aug & Sept & Oct & Nov & Dec & Jan & Feb & Mar \\
\hline $\begin{array}{c}\text { Acremonium; } \\
\text { Aspergillus niger } \\
\text { and yeast; } \\
\text { Cryptosporidium } \\
\text { and yeast; Yeasts }\end{array}$ & $\begin{array}{c}\text { Acremonium; } \\
\text { Alternaria; } \\
\text { Alternaria and } \\
\text { Cladosporium; } \\
\text { Candida; Candida } \\
\text { and Rhodotorula; } \\
\text { Candida, Mucor } \\
\text { and Aspergillus; } \\
\text { Cladosporium; } \\
\text { Cladosporium and } \\
\text { Candida; } \\
\text { Rhodotorula }\end{array}$ & $\begin{array}{c}\text { Aspergillus terreus; } \\
\text { Candida; } \\
\text { Geotrichum; } \\
\text { Mucor; } \\
\text { Penicillium and } \\
\text { Acremonium; } \\
\text { Penicillium and } \\
\text { Candida; } \\
\text { Penicillium, } \\
\text { Cladosporium and } \\
\text { Aspergillus; } \\
\text { Rhizopus and } \\
\text { Geotrichum }\end{array}$ & $\begin{array}{l}\text { Alternaria and } \\
\text { Cladosporium; } \\
\text { Candida; Candida } \\
\text { and Geotrichum; } \\
\text { Geotrichum; } \\
\text { Penicillium } \\
\end{array}$ & $\begin{array}{l}\text { Candida; Candida } \\
\text { and Geotrichum; } \\
\text { Candida; Mucor } \\
\text { and Aspergillus; } \\
\text { Geotrichum; } \\
\text { Penicillium; } \\
\text { Penicillium; } \\
\text { Cladosporium and } \\
\text { Aspergillus; Yeast }\end{array}$ & $\begin{array}{l}\text { Candida; Candida } \\
\text { and Geotrichum; } \\
\text { Penicillium; } \\
\text { Penicillium and } \\
\text { yeast }\end{array}$ & $\begin{array}{c}\text { Candida and } \\
\text { Geotrichum; } \\
\text { Penicillium; Yeast }\end{array}$ & Yeast \\
\hline
\end{tabular}




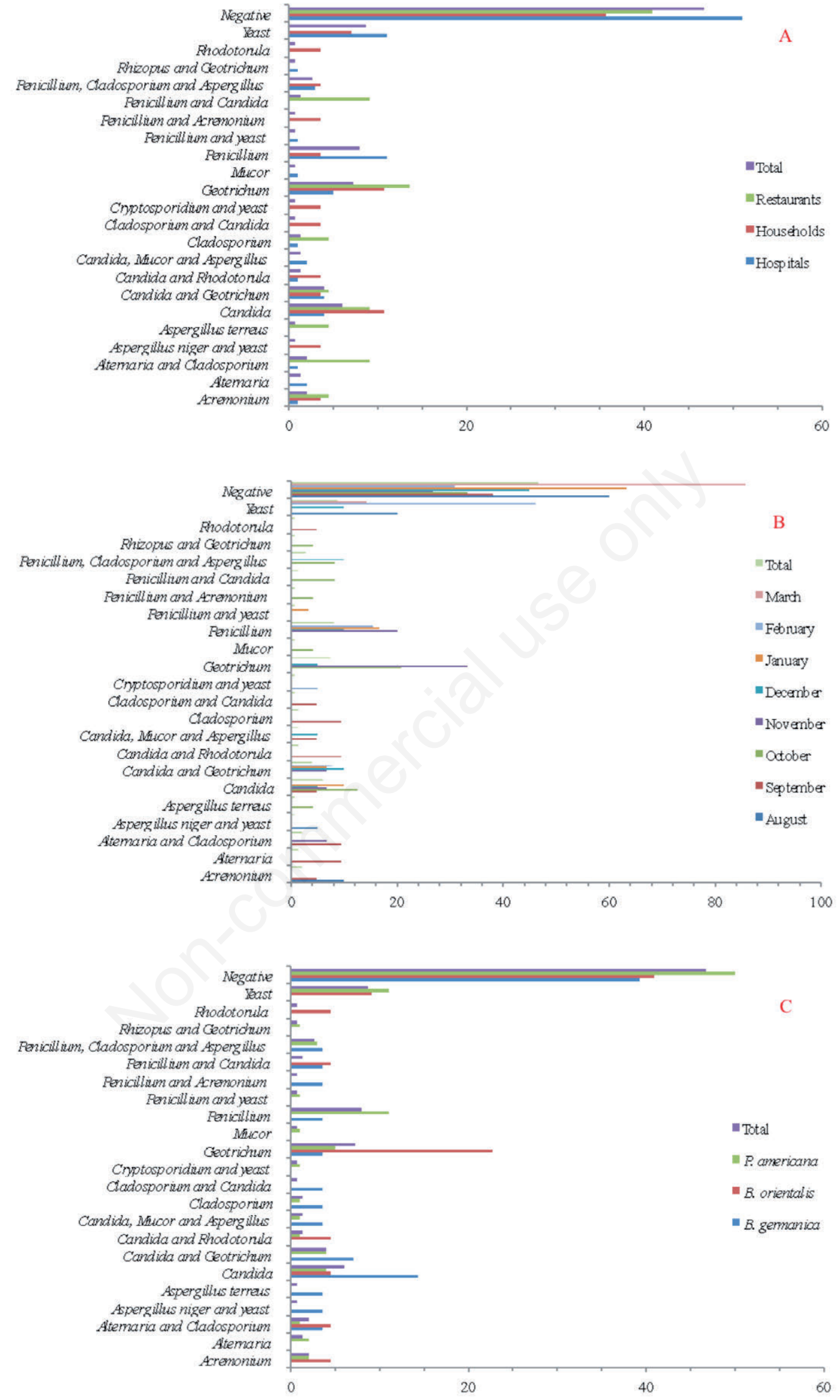

Figure 2. Cockroach fungal contamination (\%), August 2015-March 2016. A) Locality cockroach fungal contamination. B) Monthly cockroach fungal contamination. C) Cockroach species fungal contamination. 
In the present study three cockroach species including $P$. americana, B. germanica and B. orientalis were found. Different groups of fungi isolated from cockroaches in the hospital, restaurant and household environments. The diversity and dominancy of cockroach species to fungal contamination were $P$. americana, $B$. germanica and $B$. orientalis in order. Some human opportunistic pathogens were found among the cockroach fungal contaminants threatening human health. Recent epidemiological survey confirms that the mortality rates of the patients admitted to Shohada Hospital of Khorramabad are increased and the mortality rates of infective diseases were increased. It may be cockroaches involved in their transferring.
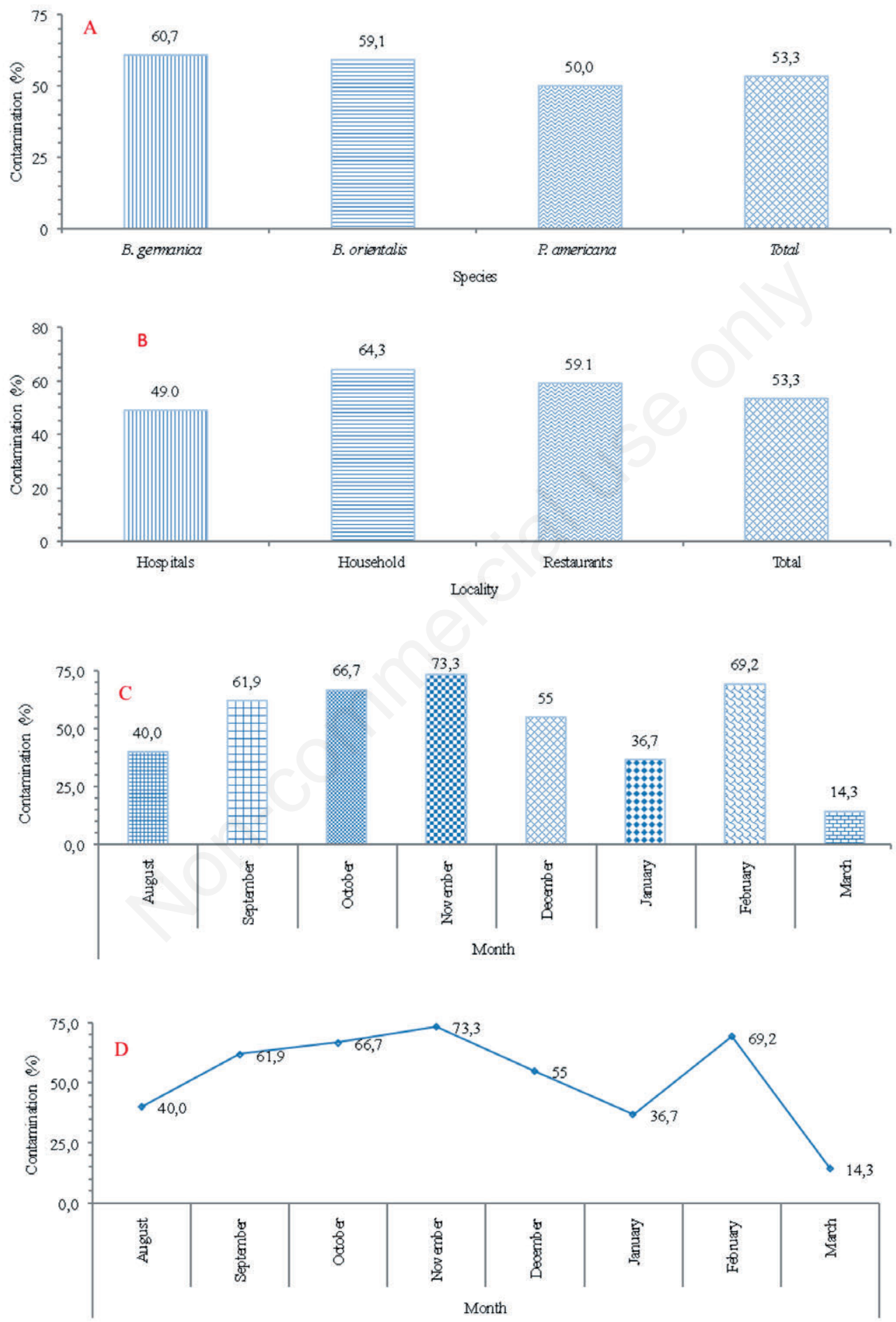

Figure 3. Cockroach fungal contamination, August 2015-March 2016. A) Cockroach species fungal contamination. B) Cockroach locality fungal contamination. C) Cockroach fungal contamination during the study. D) Trend of cockroach fungal contamination during the study. 


\section{References}

ASH N., GREENBERG B., 1980 - Vector potential of the German cockroach (Dictyoptera: Blattellidae) in dissemination of Salmonella enteritidis serotype typhimurium. - J. Med. Entomol. 17: 417-423.

CHITSAZI S., MORAVVEJ G., NADERINASAB M., 2013 Fauna of bacteria and fungi associated with digestive system of Blattela germanica L. collected from various locations in Mashhad, Iran. - Iran. J. Med. Microbiol. 6: 16-26.

DAVARI B., KALANTAR E., ZAHIRNIA A., MOOSA-KAZEMI S., 2010 - Frequency of resistance and susceptible bacteria isolated from houseflies. - J. Arthropod Borne Dis. 4: 50-5.

DAVARI B., KHODAVAISY S., ALA F. , 2012 - Isolation of fungi from housefly (Musca domestica L.) at Slaughter House and Hospital in Sanandaj, Iran. - J. Prev. Med. Hyg. 53: 172-174.

DOROODGAR A., KHORSHIDI A., SHAJARI G.R., TASHAKKOR Z., 2005 - Bacterial infection of cockroaches in Kashan hospitals, 2001. - J. Kashan Univ. Med. Sci. (FEYZ). 8: 30-38.

FOTEDAR R., BANERJEE U., 1992 - Nosocomial fungal infections: study of the possible role of cockroaches (Blattella germanica) as vectors. - Acta Trop. 50: 339-343.

KHOOBDEL M., DAVARI B., 2011 - Fauna and abundance of medically important flies of Muscidae and Fanniidae (Diptera) in Tehran, Iran. - Asian Pac. J. Trop. Med. 4: 220-223.

LADONNI H., PAKSA A., NASIRIAN H., DOROUDGAR A., ABAIE M., 2013 - Detection of Carbamat and organo phosphorus susceptibility levels in German cockroach in vivo. Toloo-e-Behdasht. 40: 95-105.

LIMOEE M., DAVARI B., MOOSA-KAZEMI S.H., 2012 - Toxicity of Pyrethroid and Organophosphorous Insecticides against Two Field Collected Strains of the German Cockroach Blattella germanica (Blattaria: Blattellidae). - J. Arthropod Borne Dis. 6: 112.

LIMOEE M., SHAYEGHI M., HEIDARI J., NASIRIAN H., LADONNI H., 2010 - Susceptibility level of hospital-collected strains of German cockroach Blattella germanica (L.) to carbamate and organophosphorous insecticides using surface contact method in Tehran (2007-2008). - J. Kermanshah Univ. Med. Sci. 13: 337-343.

MAHMOUDI G.A., ASTARAKI P., ANBARI K., KHAYATPISHEH S., 2014 - Epidemiolgical survey of mortality rate in patients admitted to Shohada Hospital of Khorramabad in 2011. - Iran. J. Forensic Med. 20: 393-400.

NADERINASAB M., MORAVVEJ G., 2012 - Bacterial and fungal contamination of cockroaches at two seasons in public habitants of Mashhad, Iran. - The 13th Iranian and the Second International Congress of Microbiology.

NASIRIAN H., 2007 - Duration of fipronil and imidacloprid gel baits toxicity against Blattella germanica strains of Iran. - J. Arthropod Borne Dis. 1: 40-47.

NASIRIAN H., 2008 - Rapid elimination of German Cockroach, Blattella germanica, by fipronil and imidacloprid gel baits. - J. Arthropod Borne Dis. 2: 37-43.

NASIRIAN H., 2010 - An overview of German cockroach, Blattella germanica, studies conducted in Iran. - Pak. J. Biol. Sci. 13:1077-1084.

NASIRIAN H., 2016 - New aspects about Supella longipalpa (Blattaria: Blattellidae). - Asian Pac. J. Trop. Biomed. 6: 10651075.

NASIRIAN H., 2017a - Contamination of cockroaches (Insecta: Blattaria) to medically fungi: A systematic review and metaanalysis. - J. Mycol. Med. 27 [in press]
NASIRIAN H., 2017b - Infestation of cockroaches (Insecta: Blattaria) in the human dwelling environments: a systematic review and meta-analysis. - Acta Trop. 167: 86-98.

NASIRIAN H., LADONNI H., ABOULHASSANI M., LIMOEE M., 2011 - Susceptibility of field populations of Blattella germanica (Blattaria: Blattellidae) to spinosad. - Pak. J. Biol. Sci. 14: 862-868.

NASIRIAN H., LADONNI H., DAVARI B., SHAYEGHI M., ERSHADI Y., REZA M., VATANDOOST H., 2006a - Effect of fipronil on permethrin sensitive and permethrin resistant strains of Blattella germanica. - J. Kurdistan Univ. Med. Sci. 11: 33-41.

NASIRIAN H., LADONNI H., SHAYEGHI M., AHMADI M.S., 2009 - Iranian non-responding contact method German cockroach permethrin resistance strains resulting from field pressure pyrethroid spraying. - Pak. J. Biol. Sci. 12: 643-647.

NASIRIAN H., LADONNI H., SHAYEGHI M., VATANDOOST H., RASSI Y., ERSHADI M.Y., RAFINEJAD J., BASSERI H., 2006b - Duration of fipronil WHO glass jar method toxicity against susceptible and feral German Cockroach strains. Pak. J. Biol. Sci. 9: 1955-1959.

NASIRIAN H., LADONNI H., SHAYEGHI M., VATANDOOST H., YAGHOOBI-ERSHADI M., RASSI Y., ABOLHASSANI M., ABAEI M., 2006c - Comparison of permethrin and fipronil toxicity against German cockroach (Dictyoptera: Blattellidae) strains. - Iran. J. Public Health. 35: 63-67.

NASIRIAN H., LADONNI H., VATANDOOST H., 2006d Duration of fipronil topical application toxicity in Blattella germanica field population strains. - Pakistan J. Biol. Sci. 9: 800-804.

NASIRIAN H., LADONNI H., VATANDOOST H., SHAYEGHEI M., POUDAT A., 2006e - Laboratory performance of $0.05 \%$ fipronil and $2.15 \%$ imidacloprid gel baits against German cockroaches, Blattella germanica. Hormozgan Med. J. 10: 24-25.

NAZARI M., ALIPOURIAN MOTLAGH B., NASIRIAN H., 2016 - Toxicity of cypermethrin and chlorpyrifos against German cockroach [Blattella germanica (Blattaria: Blattellidae)] strains from Hamadan, Iran. - Pakistan J. Biol. Sci. 19: 259-264.

PAI H.H., CHEN W.C., PENG C.F., 2004 - Cockroaches as potential vectors of nosocomial infections. - Infect. Control Hosp. Epidemiol. 25: 979-984.

PAKSA A., LADONNI H., NASIRIAN H., 2011 - Detection of malathion and chlorpyrifos resistance mechanism in German cockroaches (Blattella germanica, Insecta: Blattodea: Blattellidae) using piperonyl butoxide and tributyl phosphorotrithioate. - Hormozgan Med. J. 15: 243-253.

PAKSA A., LADONNI H., NASIRIAN H., 2012 - Comparison of PBO and DEF effects on creating bendiocarb and carbaryl insecticide resistance in German cockroach. - J. Kurdistan Univ. Med. Sci.. 17: 91-101.

STYPUŁKOWSKA-MISIUREWICZ H., PANCER K., GLINIEWICZ A., MIKULAK E., LAUDY A., PODSIADLO B., RABCZENKO D., 2005 - [Synantropic cockroaches (Blattella germanica L.) in hospital environment: microbiological hazard for patients and hospital infections risk assessment]. - Przegl. Epidemiol. 60: 609-616.

ZAEIM M., SEYEDI RASHTI M., SAEBI M., 2008 - A guide to medical entomology. Tehran: Tehran University of Medical Sciences.

ZARCHI A.A.K., VATANI H., 2009 - A survey on species and prevalence rate of bacterial agents isolated from cockroaches in three hospitals. - Vector Borne Zoonotic Dis. 9: 197-200. 